\title{
Feu et femme (Hauts plateaux du Yémen du Nord)
}

\section{Dominique Champault}

\section{OpenEdition}

Journals

Édition électronique

URL : https://journals.openedition.org/tc/886

DOI : $10.4000 /$ tc. 886

ISSN : 1952-420X

\section{Éditeur}

Éditions de l'EHESS

\section{Édition imprimée}

Date de publication : 1 février 1987

ISSN : 0248-6016

\section{Référence électronique}

Dominique Champault, «Feu et femme (Hauts plateaux du Yémen du Nord) », Techniques \& Culture [En ligne], 8| 1987, mis en ligne le 23 janvier 2006, consulté le 29 septembre 2022. URL : http:// journals.openedition.org/tc/886 ; DOI : https://doi.org/10.4000/tc.886

Ce document a été généré automatiquement le 29 septembre 2022

Tous droits réservés 


\section{Feu et femme (Hauts plateaux du Yémen du Nord)}

Dominique Champault 